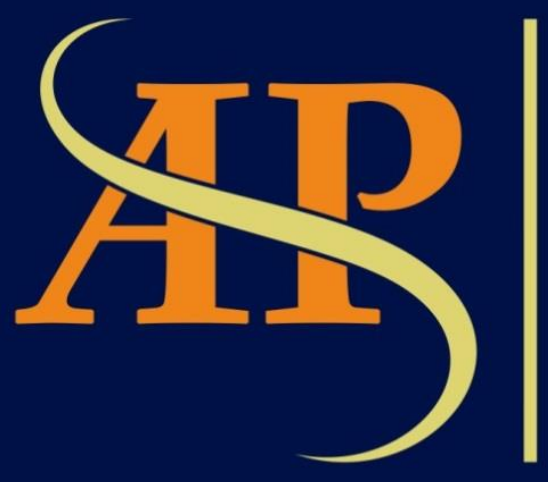

JURNAL

ASIA

PACIFIC

STUDIES

Journal of International Relations Study Program Faculty of Social and Political Sciences

Universitas Kristen Indonesia

Volume 4 | Number 1 | January- June 2020 


\begin{tabular}{r|l} 
Jurnal Asia Pacific Studies & Volume 4 Number 1/January - June 2020 \\
http://dx.doi.org/10.33541/japs.v4i1.1556 & pp. $72-85$
\end{tabular}

\title{
China`s Digital as Counterweight Asia-Pacific Century
}

\author{
Bayu Altaer \\ International Relations, Faculty Social and Political Sciences, Syarif Hidayatullah State Islamic University \\ Jakarta, Jl. Ir H. Juanda No. 95, South Tangerang City 15412 \\ bayualtaer@gmail.com
}

\begin{abstract}
China's digital transformation has been made China's digital economic capabilities awake sharply. The digitalization of China is determined by several factors which are based on the current globalization. The Chinese government also plays an active role in accelerating domestic digital transition process and core in way of intensive cooperation with countries in Asia Pacific region. Changes in Chinese orientation using a digital approach create anxiety for the United States of America with the emergence of China axis in region. The framework of the article uses the concept of digitalization to describe the process of digital transformation in China, then Neo-liberalism theory of Robert Keohane \& Joseph Nye to explain the pattern of China's cooperation with the region and the Balance of Power as a middle-range theory to emphasize the emergence of China's digital axis in Asia-Pacific. Using descriptive qualitative methods and collecting literature study data, this article emphasizes the analysis of the magnitude effect of digitizing China as a new axis in the Asia Pacific region as competitors in the United States and Australia. The digitalization and intensification of cooperation believed to be the main variable in balancing political economy axis at the regional level.
\end{abstract}

Keywords: China Digital, Cooperation, Digital Economic Capability

\begin{abstract}
Abstrak
Transformasi digital China telah membuat kapabilitas ekonomi China meningkat tajam. Digitalisasi China dideterminasi oleh beberapa faktor yang didasari oleh adanya arus globalisasi. Pemerintah China juga berperan aktif mempercepat proses transisi digital domestik serta menjadi kunci jalannya kerjasama kerjasama intensif dengan negara dikawasan Asia Pasifik Perubahan orientasi China menggunakan pendekatan digital menciptakan kekhawatiran bagi Amerika Serikat akan munculnya poros China dikawasan. Kerangka pemikiran artikel menggunakan konsep Digitalisasi untuk menggambarkan proses transformasi digital di China, teori Neoliberalisme versi Robert Keohanne \& Joseph Nye untuk menjelaskan pola kerjasama China dengan negara dikawasan dan teori Balance of Power sebagai middle-range teori untuk menekankan kemunculan poros digital China di Asia-Pasific. Dengan menggunakan metode deskriptif kualitatif dan pengumpulan data studi literatur, artikel ini menekankan pada analisis besarnya pengaruh digitalisasi China sebagai poros baru dikawasan Asia Pasifik sebagai kompetitor Amerika Serikat dan Australia. Digitalisasi dan intensifikasi kerjasama diyakini menjadi variabel utama penyeimbang poros ekonomi politik dilevel regional.
\end{abstract}

Kata Kunci: Digital China, Kerjasama, Kapabilitas Digital Ekonomi 


\section{Introduction}

\subsection{Background}

Globalization has become a new determinant factor in the International Relations studies approach. Not only changes in terms of theoretical nor practical studies, but also shift the phenomena that were not previously imagined by IR scholars. Digital-based transformation and intensification of cooperation in the era of globalization are "compulsion" around the world. Digitalization and intensification of cooperation "cannot be denied" has its own benefits in increasing the capability and competitiveness of country. This also happened in the area studies of Australia and Pacific.

In terms of digitalization, China considered as a large digital-based industry state whose influence has been recognized. China Digital is an online data network to make strategies one directly adapted on the China local market and blow up international commodity. China offers a new way to gather resources and capabilities to make an indigenous impact with virtual benefits. For almost a decade of process and experiences, China can lead massive international clients to achieve and surpass their expectations in online marketing goals.

The achievement can be made by the Chinese government through the "China Digital Landscape" which is; E-Commerce, Online Gaming, Network Providers, Video Sharing, Customer Review, BBS, BBS Aggregators, Instant Messaging, Micro Blogging, E-Banking, Life Streams, Social Networks, Music, Photos, Location Based Services, Social Bookmarks, Blogs, Wiki, Q\&A, RSS (Zhu 2013). In the case of e-commerce, past decades China accounted for less than $1 \%$ of total value transactions worldwide, but now exceeds $40 \%$ with all velocities larger than France, Germany, United Kingdom, United States and Japan (K. W. Wang 2017).

According to the McKinsey Global Institute report by Kevin Wei Wang, "China is already a global leader in the digital economy ..... but there is much more to come, a new wave of digitalization is now unfolding in which many more businesses put the digital at the heart of their operations and strategy. " (K. W. Wang 2017, 5) . Digitalization of China has changed the global axis especially in the Asia-Pacific region where Australia and its allies the United States are beginning to feel shifting power in regional influence.

This articles argues that China become the new counterweight pivot in the Asia Pacific region competing with the United States and Australia. Digitalization and intensification of cooperation is believed to be a balancing variable at the regional level. In this phase, the interests of the country in the Asia Pacific region are at stake and can become a new location for international political economy contestation.

\subsection{Problem Identification}

Based on the introduction section above, the only main problem from China counterweight in the Asia-Pacific region is how far the influence exerted by China through its digitalization and potential cooperation towards the monitoring of the axis of Western country allies in the region. Considering that the United States has full control over Asia pasific activities through its satellite countries, South Korea and Japan.

Another potential problem which is more serious and should be taken into account, but not the main proper discussion in this article is that the clarity threat of the US-China trade war and its correlation to military tension between these two countries in South China Sea, then how Australia's position faces the situation. Australia's interests in the Asia Pacific have 
been recognized, but if these threats continue and more escalate, they will certainly affect the future of the Australian political economy, so of course Australia must take a part and consider it foreign attitudes and policies responding to the situation.

\subsection{Purpose and Objective}

This article would highlight the explosive increment in digitalization trend that has been accrued in China along with the resulting economy consequences based on domestic policy factors and foreign policy. This article uses a qualitative descriptive method with data collection through literature study to recite the objectives focuses on China with its confrontation to the United States and Australia allies in the Asiapasific region.

\subsection{Benefits of the Research}

The finding embedded in this article can be used to understand the tendency of shifting power in the Asian region. China digital in particular has a direct impact with political conditions to western allies. This article may hep to understand readers of "how" China can create counterweight willings so that the United States and Australia feel apprehensive. Also can be used to guess the Australian attitude if the situation in the region is getting worst.

\section{Literature Review and Framework of Thingking}

\subsection{Neoliberalism}

Neoliberalism is a general theory (Grand Theory) in the study of international relations which appear as a theory that focuses on the explanation of to which extent countries in the international system can create a stable world order (without war) through cooperation. The collaboration was implemented in various ways including through inter-state cooperation and institutional control (Keohanne 1941, 57). Neoliberalism stresses that in terms of cooperation the state will refrain from responding to threats in a repressive way, the state will be more persuasive using the method of absolute gain or non-zero sum game where each actor can influence each other in achieving its goals thereby creating a peaceful regional situation.

Neoliberal provides the view that peace can be built through interdependent patterns of cooperation. This cooperation can be seen through export-import activities which are the foundation of any countries meeting their basic needs of the country. The majority of countries in the world carry out export-import activities in order to meet all the needs of the country to achieve their national interests. (Keohanne 1941, 63). A part from the ideology adopted by any country, intensive export-import activities have shown cooperation and interpreted as a patterns of economic liberalism in creating interdependence in the existing international system.

Interdependence as a concept coined by Neo-Liberalism thinkers which means reciprocal dependence assumes that the level of intensity of cooperative relations determines with the level of interdependent relations of a country (Jackson and Sorensen 2013, 182). In the contemporary era, economic interdependence is an international phenomenon that is prevalent with the digitization of industry 4.0, the state does so intending to adjust the pace of the economic acceleration.

"Interdependence affects world politics and behavior of state, but governmental actions also influence patterns of interdependence" (Keohane and Nye 1989, 5). Keohanne 
and Nye show interdependence as a common phenomenon applied by the state. The digitalization and intensification of cooperation makes actors bound to a strategic performance, but the state remains as the main key factor in regulating that pace of complex cooperation to suit its national interests.

The concept of interdependence in the Neoliberal Theory used in this article to explain the state of a country which maximizes cooperation and spreads influence on actors in the international system. Utilization of digitalization and maximization of the country's potential is the basis for the intensification of the state to carry out cooperation so that it can strengthen the country's existence in the region.

\subsection{Balance of Power}

Balance of Power (BOP) is proven and well-known idea debated in theoretical concept in International Relations (IR) studies as a 'Middle range theory'. Although BOP is a conceptual theory that was coined and closely related to the theory of realism, but actually BOP has an adjustment in its function depending on which theory the concept is applied.

"There are so many versions of balance-of-power theory that we cannot even list them all," (Wohlforth, Little and Kaufman 2007, 157). Therefore, this article will look at BOP in the rectification of Neo-liberal theory. The stability offered by neoliberalism is rooted in the complex relations of dependence (previously described) in which contemporary world countries collaborate intensively with one another, thus creating a state of equilibrium on the basis of economic motives.

Neoliberalism recognizes the existence of an anarchic international system assumed by neorealism and there is an endogenous balance of power effort, for example neoliberal institutionalism that encourages international affairs as a constituent system (Niou and Ordeshook 1991, 483), so that the concept of BOP in a region can be manifested as a condition of the empirical area studies.

The conception of BOP can be assumed as a state proportion of power that exists in an anarchic international system, the proportion of that power is the capability from the power possessed by the state and the state of BOP is born when other countries feel there is a sensitivity to the change in power (possibly threatening), so it requires a state of balance of power both from internal (consolidating/strengthening own capabilities) or from outside (aggregating alliances). It should be underlined that the 'power' does not always tend to security issue, power also include the capability that owned so that state can perceived to have more competitiveness which in this article tends to be the international political economy.

The concept of BOP in this article is used to explain the influence of China's digital power balance facing the axis of western power, which are the United States and Australia in the Asia Pacific region. BOP tends to represent hegemonic concerns and the emergence of competition between countries in certain regions.

\subsection{Digitalization}

Globalization that has penetrated the industry assets has changed the face of worldwide to be full of economic acceleration with rapid technological change. This creates new opportunities and challenges industrie to more flexible, interconnectivity and productive. This situation can be understood by term digitalization. "Digitalization is the process of converting analogue data into digital data sets which exploits digital opportunities like digital 
transformation. Used for restructure economies, institutions and society at system level" (Rachinger 2019, 1144).

Simply, digitalization can be interpreted as a process of becoming digital, to getting ease and profit following the rate of technological acceleration and globalization. Digitalization has a direct impact on many countries, not only on corporate and industry actors but also middle-low rooted entrepreneurs. The reason is that digitalization carried out massively on all lines can fully encourage commodities and local potential with all the available facilities.

It should also be stressed that the transformation of digitalization is also in line with the existence of internet facilities as a unified of whole digitalization. As a result, digitalization was not only simplifying and accelerates the process of national development but also increases connectivity and relationships that adds more value.

In this article, digitalization is used as a determinant factor for China to strengthen its existence in the Asia Pacific region. As one of the new approaches in regional studies, the concept of digitalization can be considered in IR discussions given that there have been many transformations of contemporary IR phenomena.

\subsection{Literature Review}

Critical Engagement on Digital Sovereignty in International Relations: Actor Transformations and Global Hierarchy In a journal article by Abid A. Adonis published in Global: Journal of International Politics, the University of Indonesia discusses the issue of digital sovereignty as an important discussion of contemporary international relations. The existence of digital sovereignty creates discourse because there are global-level political consequences where the influence is also of international economic politics. The effect of digitalization on the issue of sovereignty has touched on the sensitive side of state sovereignty. Until finally what became the starting point of digital sovereignty was the state's important position in the political-security field. This emphasis can be seen from the approaches in the article that discuss digital dimensions at the global level which have transformed and become much more dynamic.

The method used in this article is through intensive literature review by collecting several articles and scientific sources and then classifying them into several focuses, including the Concept of Development and Digital Sovereignty, Actors in Digital Sovereignty, Government Internet, and the categories of issues that exist in Digital Sovereignty. The article by Abid A. Adonis concludes and agrees that digital sovereignty is an important discussion and issue and can be considered by academics given the fact that data transformation is making massive accessibility used by the entire world.

The difference between the author's journal article and this article lies in the focus of his study, Abid's article focuses on the extent to which digital is able to influence the conception of sovereignty and the surrounding institutions, while the author's article focuses on digital china which is the axis of the Chinese economy in the Region.

Another literature study that discusses the importance of China's Belt and Road Initiative (BRI) in the region is understood as a contemporary vision of continuing the historical struggle of the previous One Belt One Road (OBOR). In Muhammad Akbar's article in the Journal of Asia Pacific Studies entitled Belt and Road Initiative (BRI) and its implications on maritime security in Asia: Case Study on China-Australia Trade Cooperation, BRI is discussed with the implication of China strengthening its maritime axis through the reach of economic cooperation. In addition, the article examines China's efforts to try to use Soft Power through trade and economy instruments. "China then targeted Victoria Government as the representation of Australia to sign and legalized the cooperation concerning specific issues, which is BRI". Therefore, the difference with this 
article lies in the focus of the study. The article focuses on examining the extent to which ChinaAustralia economic cooperation can be interpreted as an effort to realize BRI China, while this article focuses on the extent to which China is digital can create a new axis in the region.

Another literature main resource come from annual report of McKinsey Global Institute (MGI) that assesses and draft the strengths of China's digital system also digitization of industries. This report understanding that there is an order to analyze how far digitization is shifted status quo and creating new challenge of China`s power digital forces with disintermediation, disaggregation, and dematerialization. These factor restructured way of value chains and emphasize policy makers decision in facilitated the transition toward a digital economy. "China sets the world's digital frontier in coming years. China's increasing prominence on the world's digital stage also means that the country can contribute, and even lead, broader debates on global governance issues such as barriers to foreign competition, reciprocity, and digital sovereignty".

\section{Result and Discussion}

\subsection{Transforming China`s Digital}

China`s digital can be assumed as the activity of transforming human aspect in lives into digital (computer machines) on all fronts. The intention aspects of activities that occur have been switched to computerized with media and digit numbers (algorithms). Usually the phenomenon of digitalization also coincided with the use of the internet (data network access), so that digitalization can affects dan spread various aspects. Digitalization that occurred in China quickly implement, has been able increase economic capacity massively and internationally.

Entering the $20^{\text {th }}$ century, China`s digital began with large numbers of digital consumer, certainly it was affect by the large population in China. In 2013, there were 632 million active users with a comparison of 800 million item products and 231 million active emarket buyers (Kable ICT Customer Survey 2013), even recorded 772 million users in 2017 and 802 million users in 2018 (China Internet Network Information Center 2018), some make sense this figure is almost $3 \mathrm{x}$ total population of Indonesia.

Along with large scale digital used, Chinese people also take this advantage of digitizing data to learn 'digital-tech' in order to apply digital facilities from digital consumer state to a digital driven state. The Chinese government provides stimulus to traditional industries inform of research funding assistance and large capital loans in order to create modern industries and digital enterprises that able to manage international market share. "A great wave of disruption has just begun, and companies that move quickly can realize both significant cost savings and advantages in fast-evolving new markets" (China Internet Network Information Center 2014).

Through incentives from the Chinese government, businesses and companies are successfully integrated web technologies into their operations. Entrepreneurs manager requires up-front investment, digital skill sets, a setting of organizational composition with a digital mindset oriented. But the gain-loss obtained both for grassroots entrepreneurs or for the broader economy can be more huge profitable.

The Chinese government has issued an active policy to support and command the acceleration of approach to digitization. It is regulate digital efflorescent sector and gives companies plenty in transforming their digital empowerment. Today, Chinese government is regulating an active role in constructing world-class digital facilitation to support developers, investors and consumers. To sharpen the contribution of the government, this article first 
describes the government's active role through a government role that is not only a policymaker but also an investor, innovator, and consumer to support digitization with some incentives.

The government has advanced some policies to amplify the digital economy as a new force of economic growth. One of them in 2015 the government revealed the concept of the "Internet Plus" conjunction with an action plan to integrate the internet, cloud computing, big data, and IoT with traditional manufacturing and consumer industries (The State Council RRC 2015). Another way in June 2017, Shanghai launched integrated internet shipping port, which merge e-commerce companies in shipping logistics, data analytics, related financial and legal services, and office space (Z. Wang 2017). In fundings, the government has encouraged citizens to participate in mass entrepreneurship using tax deductions and state-endorsed startup funds. In August 2016, there is establishment $\$ 30$ billion of a state-owned venture capital fund in Shenzhen, home to many digital startups (Custer 2016), in Beijing Zhongguancun Inno-Way, high-tech goverment communities known as China's Silicon Valley, launched 500 million renminbi (\$75.3 million) in venture capital fund. The government also command the commercialization of new technologies through stateowned enterprises (SOEs) wich are China Mobile, China Unicom, and China Telecom. Fund has been spend up to $\$ 180$ billion in seven years on goverment vision as the world's largest $5 \mathrm{G}$ mobile network (Li 2017). With large subsidies provided by the government, China digital has reached full optimal expense to increase total domestic capacity in maximazing national foreign exchange income.

\subsection{Digitalized China Power}

As elaborated in transforming China`s digital, there is a shifting orientation that makes 'digital' as the main platform for developing China's power capabilities. This digitalization can penetrate more deeply across major sectors, especially in political-economy. Many local industries and domestic companies have embraced digital web technologies, operations become more efficient and increased productivity gains. After almost all aspects of the economy in China have been digitalized, new markets and variable works for innovative products and services are created. Thus, employment with demand for digital competitive skills created.

The e-commerce marketplaces Taobao and Tmall in issues posted more than almost $\$$ 6 billion in sales just 24 hours. Some five billion daily searches are made through Baidu, and hundreds of millions communicate via WeChat, Tencent's mobile messaging app. With the reality of the digitization, China through digital internet instruments has achieved economic stability based on the GDP growth rate. Depending on the speed and extent of industry adoption on digital innovation, digital internet could add $0.3-1.0 \%$ points to China's GDP growth rate. Then increase could fuel some $7-22 \%$ of the incremental GDP growth expected in 2025 or equal with 4 trillion - 14 trillion yuan in annual GDP (McKinsey Global Institute 2014). 
Tabel 1. Extent of Internet adoption to China`s future economic growth

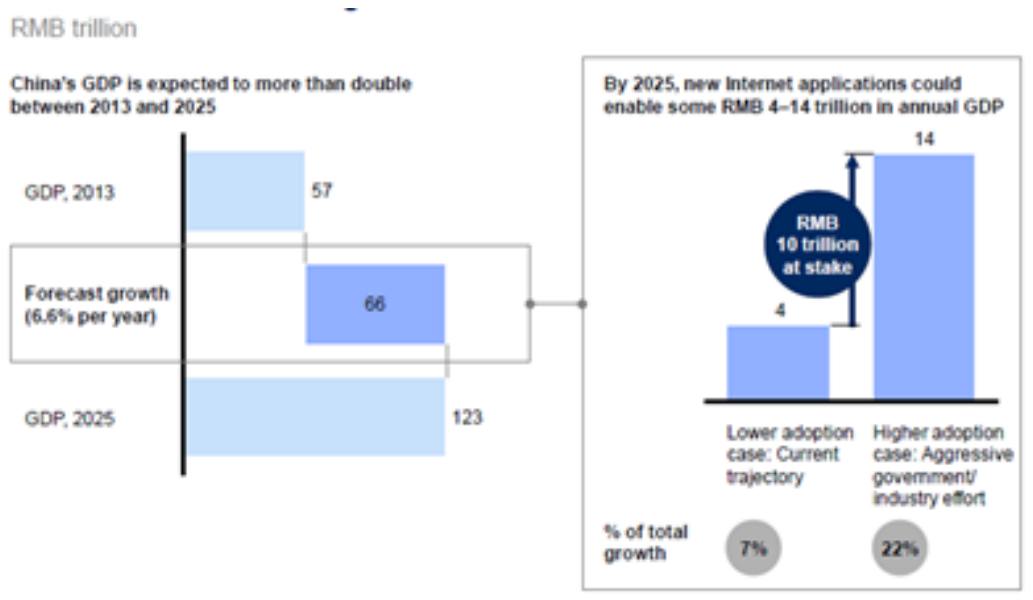

NOTE: Numbers may not sum due to rounding.

Source: McKinsey Global Institute Analysis (in McKinsey report 2014, 4)

Quoting the statement of researchers from the University of Chicago, "The Internet will not only create economic momentum for China in the years ahead, it will also change the very nature of growth. The heavy capital investment and labor force expansion that fueled China's rise over the past two decades cannot be sustained indefinitely. It accelerates the development of market forces, and as it heightens competitive intensity, the most efficient enterprises and best practices win out "(Lewis 2005). As logic the power shifting from China lead by its digital compromised, blow up economic capacity that's never seen before and attracted another country in region to cooperate in term of political economy pledged.

\subsection{China`s Counterweight Sectors}

After learning about the changing face of the industry and the ability of the Chinese economy through its digitalization, this article concludes that there are a number of supporting sectors that driving China's economic capacity in the region. These are six sectors represent mix of Chinese industry and services that have special discrete and manufacturing processes. China companies are beginning to revamp traditional business processes to achieve cost savings, and other cases add new billion-dollar markets to shape virtually weight. 
Tabel 2. Adoption of Digital Application to Substansial Economic Sector

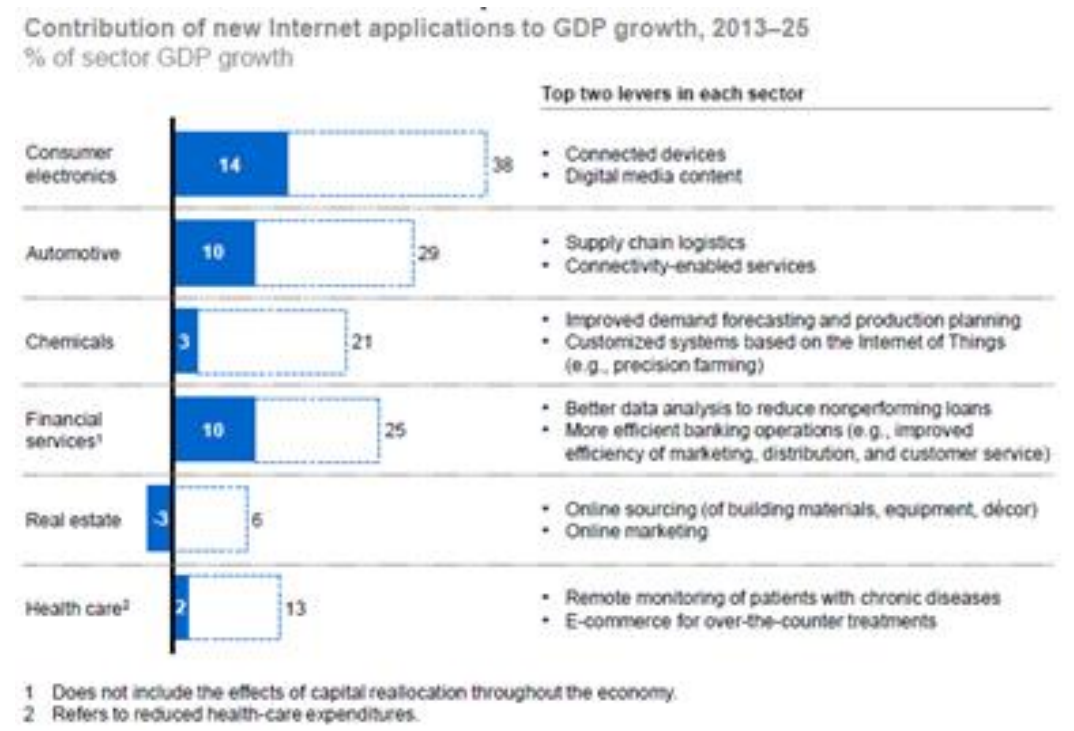

Source: McKinsey Global Institute Analysis (in McKinsey 2014, 7)

The digital internet applications sector above can determine the ongoing process of moving China's industry from less productive to more technologically advanced business models. Partially, the sector has brought China into New Emerging Power in the Asia Pacific because it is able to accommodate each sector by many other sectors, countries in the region establishing economic cooperation with China as superior actor in those sector. Consumer electronics lead Chinese GDP grotwh because with digital connection as primary digital lane made other sector adapt implemently and practicaly digitalized. Other sector, as a second lead substansial economic is automotive services. Asian automotive industry, especially China automotive has dominated vehicle products in the world. Addition with more economical prices for middle-low class consumer, Chinese automotive product also known to be efficient and thrift fuel, with digitalization automotive industry increase brightly control world market share. Another sector like financial service, real estate/ tourist services and health care has mainstay benefitfull sector to gain operational services quality product offerings. China can also emphasize its influence in the region due to the fabric of economic cooperation, therefore basically the transforming digital and digitalized sectors of China will be nil without exportimport activities. "Chinese trade with other countries has exceeded its national economic activity, for around 60-70\% affecting its domestic economy" (Cheng 2011), So, can be said that it is almost impossible for China to sustain its economy without trading with other countries.

China as a major worldwide investor in digital has overseas venture capital companies investors. China's outbound venture capital totaled $\$ 38$ billion in 2014-16, reaching 14 percent of global venture capital investment outside China.61 About 80 percent of investment advanced economies and approximately 75 percent was invested in digital-related sectors. Clearly,China's influence in the global startup market is growing rapidly as drives technology, talent, and products and services. China's companies made 35 overseas deals, compared with 20 by the top three US internet companies. Tencent generates more than $10 \%$ of global gaming revenue, making it the largest gaming company in the world.62 In 2016, Alibaba invested \$1 billion to acquire a controlling interest in leading e-commerce platform Lazada, which has 550 million customers in six Southeast Asian countries. (McKinsey Global 
Institute 2017). Several multinational companies are influential on changes economic axis thorugh digital investment channels.

With China's high digital capability, not only the Pacific countries are carrying out economic cooperation, but almost all countries trade even their rivals, the United States. Digital China has formed varied patterns of Chinese cooperation, not only in investment but also in export-import activities. The advantages that China has both its population, large capital and its digitalization have brought the strategic sector of cooperation with China increasingly strategic. Food export cooperation is running more optimally because domestic digitalization has been consolidated. Industrial cooperation both commercial products (electronics, clothing and food) and fundamental products (health care, technology industry, infrastructure) take place more efficiently with the implementation of sophisticated tools, service and service cooperation (institutions and education) are also more intensive because digitalization is able to facilitate service priorities and company cooperation is more profitable because of the ease that can be accessed and promising each other.

Therefore, it is not surprising if the countries in the Pacific region depend a lot on China. The cooperation formed in the region has shown neoliberalism as the basis for the state to fulfill its national interests by holding various sectoral collaborations. Interdependence is also formed on the high intensity of ongoing cooperation and touches important sectors in the Pacific. In general, digital China has been able to attract the attention of countries in the region and provide political-economic ties. The rapid capability possessed by China has fulfilled the needs of other countries in the region, especially jointly developed cooperation usually does not require complicated and more profitable requirements.

\subsection{Confrontation China`s Economic Militarization}

The existence of China in region continuesly increase its economic influence and has frightening the United States. The "Rising of China" adage becomes even more apparent when the United States acts to enforce the Trade War with China. However, the situation was more and more worst when China also intensified its military power. After China succeded in identifying its interdependence economy in regions and other countries, so Chinese government takes more focus on the accessibility of the Ocean as a means of economic activity, China then takes responsibility in Maritime Security especially on the South Chinese Sea.

However, as well known, the United States also unhappy with this policy plus China declared "Nine Dash Line" as the acquisition of militarization of sea area and "Air Defense Identification Zone (ADIZ)" as a territory of China's air defense sovereignty. With these posts military force in some of the strategic locations, China believes it can create a safe atmosphere that may foster business acceleration. Again so, China realized can not open war soonly and would not compete head-to-head with the United States an arms race, but Xi Jinping consider military means is undoubtedly important. The demonstration of China's naval and air defense revival in Asia-Pacific is one of the instruments in convincing its cooperation partners that it is safe for doing business with China, these part seem as BOP of China accession toward the United States core exist.

China contemporary take more control in anything their length and their sight as long as it is beneficial and potentially contribute with China economics. The node of competition from China-US trade war and Sout Chinese Sea confrontation lies in the term of "Digital Silk Road Cooperation", it means China has interest to make another past imitation of OBOR strenghtened embed effect in region. 


\subsection{Australian Position in US-China Confrontation}

The great ally of the United States in the region which is Australia also has close relations later this year, particularly in the economic sector. China is the largest economic partner in Australia with total investment \$ 13 million in 2017 and mining reaching \$ 874 million (Janda 2019), therefore, Australia is pretty much depend on the economic sector with China.

In addition to investment, China also the largest export share for Australian products. There is a trend shifting orientation of Australian Trade as quoted by LIPI researcher Muhammad Akbar in the Asia Pacific study journal, describing the results of the Department of Foreign Affairs and Trade (DFAT) report released on 4 February 2019 conclude there was a gradual decline in trends in the trade activity of Australia-USA. From 9.5\% share in 2003 has fallen to $5.1 \%$ in 2013 . However in otherside, mount of trade with China increse from $8.4 \%$ in 2013 to $32.5 \%$ in 2013 (Akbar 2019). This interpretates that China is the most important country for Australian businessmen to export their service and products

But it cannot be simplified that the United States is no longer Australia's best ally, because if it is associated with trends with current economic and trade conditions, Australia certainly the closest US alliance in the region. When China and the USA are declaring trade war by increasing tariffs off goods, especially in soybean exports and limitation of Xiaomi brand products. Of course China will adjust its economic conditions through expansion in region, including to Australia, political-economic policy that maneuvers China impact trade relations with Australia and vice-versa.

In the case of escalating war tension in the South Chinese Sea, Australia will continue to side with the United States. Surely, the economic relations that exist between Australia and China will break even diplomatic relations. Then, this definitely has a spillover effect that Australia itself did not expect. If the China-USA war happens, Australia will suffer drastic losses and national economic setbacks, domestic political situation will certainly be chaotic and forced to be increasingly dependent on the aid of the USA loan itself. The worst-case scenario is if the USA provides economic assistance to Australia on condition that it must participate in providing military assistance. Australia will face a dilemma, which is to be involved in the Pacific war with China which has been a source of foreign exchange for his country or choose to remain silent by siding with the United States but waiting for the war to end with the consequences of losing its influence in the region and losing economic security.

In this case, it can be concluded that Australia will be a counterweight to China and the United States. Australia will choose the middle option by holding the United States from escalating in the South China Sea and providing economic policy and incentives to China so not invite and not take responsible instability in the region by reducing militarization and focusing on economic sector studies.

\section{Conclusion and Recommendation}

Based on the data presentation and analysis, it can be concluded that Digital China has a lot of influences so that it can influence the axis presence in the region. The influence starts from a long journey of digital concepts in China to be implemented into what it is today. China has the advantage of a high population level, so the level of digital users is also high.

The increase is very sharp every year, in 2013 as many as 632 million increased by almost 200 million in 2017 to around 800 active digital users. But what's interesting is the high use of digital (China Digital Consumer) is offset by high research and implementation efforts so that digitalization can be applied to the domestic sector. This can be seen from the 
efforts of the Chinese government to issue various policies to accelerate the implementation of digitalization. Encouragement in the form of infrastructure and facility procurement policies that are able to consolidate digitalization as well as the construction of integrated internet shipping ports, which include e-commerce companies in shipping logistics, data analytics, related financial and legal services, and office space in one area, while also prioritizing policies digital aspects both to the public, government and business actors to transform digital use in all their activities. The government also provides funding incentives to companies oriented to capital ventures or state companies.

This transformation has made China excel in digital capabilities. This state changes the orientation of 'digital' as the main platform for developing domestic capabilities. This digitalization is enforced across major sectors, especially in the political-economy sector. Depending on the speed and extent of industry adoption on digital innovation, digital internet could add $0.3-1.0 \%$ points to China's GDP growth rate. Then increase could fuel some 7 $22 \%$ of the incremental GDP growth expected in 2025 or equal with 4 trillion - 14 trillion yuan in annual GDP. The sector is the sector that has been able to apply digital as a basis for in-outcome effectively creating an impetus for increasing GDP annual growth. This transformation has created many changes that have never been imagined before, because the capabilities achieved have not only changed domestic conditions. The Chinese government is carrying out economic cooperation with other countries in the region with various approaches. Both the approach to investment, production, consumption, goods and services, to teleconomics.

In addition to the interdependent cooperation, China has also aggressively increased the military zone in the region through the militarization of the maritime region in the South China Sea and ADIZ throughout the declaration zone. This militarization is basically a form of effort by the Chinese government to secure trade and cooperation areas to secure crucial areas for the course of economic cooperation in the region. This is the situation that created the BOP concept in the region due to China being an empirical case. The United States initially worried about the influence of the Chinese economy in the region, but this militarization created the tension of military threats to be more prestigious and attracted attention because Australia's involvement between the two parties determined the future of security in the Asia Pacific region. 


\section{REFERENCES}

\section{Books}

Jackson, Robert, dan George Sorensen.2013. Introduction to International Relations: Theories and Approaches. New York: Oxford University Press.

Kable ICT Customer Survey.2013. "International Data Corporation." McKinsey Global Institute Analyses. Shanghai: China Internet Network Information center.

Keohane, Robert Owen, dan Joseph S. Nye.1989. Power and Interdependence. New York: HarperCollins Publisher.

Keohane, Robert Owen.1941. After hegemony: Cooperation and Discord in the World Political Economy. New Jersey: Pricenton Univesity Press.

Lewis, William W. 2005. The Power of Productivity: Wealth, Poverty and The Threat to Global Stability. Chicago: University of Chicago Press.

McKinsey Global Institute. 2014.China`s Digital Transformation: The Internets Impact on Productivity and Growth. Summary Book, London: McKinsey\&Company.

Wang, Kevin Wei.2017. Digital China: Powering the Economy to Global Competitiveness. New York: McKinesy Global Institute.

\section{Journal}

Akbar, Muhammad.2019. "Belt and Road Initiative (BRI) and Its Implication on Maritime Security in Asia Pacific: Case study on China-Australia Trade Cooperation." Journal Asia Pasific Studies 1-10.

Niou, Emerson M. S., dan Peter C. Ordeshook.1991. "Realisme vs Neoliberalisme: A Formulation." American Journal of Political Science 481-511.

Rachinger, Michael. 2019."Digitalization and its influence on business model innovation." Journal of Manufacturing Technology Management 1143-1160.

Wohlforth, Wiiliam C., Richard Little, dan Stuart J. Kaufman.2007. "Testing Balance-ofPower Theory in World History." European Journal of International Relations, 156185.

\section{Report}

China Internet Network Information Center.2014. The 33rd Statistical Report on Internet Development in China. Statistical Report, Beijing: China Internet Network Information Center.

China Internet Network Information Center.2018. The 41th Statistical Report on Internet Development in China. Statistical Report, Beijing: China Internet Network Information Center.

Custer, C. 2016. China`s goverment establish $\$ 30$ billion VC fund. Report proceeding, Tech in Asia.

McKinsey Global Institute 2017. China s role in the next phase of globalization. Shanghai: McKinsey Global Institute discussion paper.

The State Council RRC. 2015. China unveils Internet Plus action plan to fuel growth. Press release, Beijing: The State Council of The People`s Republic of China Publications.

WTO. 2019. World Trade Statistical Review. Geneva: WTO. 


\section{Website}

Cheng, Dean. 2011. Sea Power and the Chinese State: China`s Maritime Ambitions. accessed on April 6, 2020. https://www.heritage.org/asia/report/sea-power-and-the-chinesestate-chinas-maritimeambitions.

Janda, Michael. 2019. ABC News Letter. Accessed on April 1, 2020. https://www.google.com/amp/amp.abc.net.au/article/1098008.

Li, Xiaoyu. 2017. "Innoway launches its first 500 million RMB startup VC with focus on AI." South China Morning Post. Accessed on April 14, 2020. https://news.xinhunet.com/fortune/c_129626451.htm).

Wang, Zhiyan .2017. "China launched its first "internet plus" shipping industry base in Lujiazui." Shanghai Observer. Accessed on April 13, 2020http://sh.eastday.com/m/20170623/ulai10669236/html..

Zhu, Weinjing.2013. An infographics of Chinese digital landscape category. Accessed on April 14, 2020.

http://www.theworldofchinese.com/2013/05/the-chinese-digital-landscape/. 